\title{
Review Article \\ Prediction and Prevention of Acute Kidney Injury after Cardiac Surgery
}

\author{
Su Rin Shin, ${ }^{1,2}$ Won Ho Kim, ${ }^{3}$ Dong Joon Kim, ${ }^{4}$ Il-Woo Shin, ${ }^{5}$ and Ju-Tae Sohn ${ }^{5}$ \\ ${ }^{1}$ Department of Internal Medicine, Samsung Changwon Hospital, Sungkyunkwan University School of Medicine, \\ Changwon 51353, Republic of Korea \\ ${ }^{2}$ Department of Internal Medicine, College of Medicine, Kangwon National University, Chuncheon 24341, Republic of Korea \\ ${ }^{3}$ Department of Anesthesiology and Pain Medicine, Seoul National University Hospital, Seoul 03080, Republic of Korea \\ ${ }^{4}$ Department of Anesthesiology and Pain Medicine, Samsung Changwon Hospital, Sungkyunkwan University School of Medicine, \\ Changwon 51353, Republic of Korea \\ ${ }^{5}$ Department of Anesthesiology and Pain Medicine, Gyeongsang National University Hospital, \\ Gyeongsang National University School of Medicine, Jinju 52727, Republic of Korea
}

Correspondence should be addressed to Won Ho Kim; wonhokim.ane@gmail.com

Received 14 January 2016; Revised 25 May 2016; Accepted 29 May 2016

Academic Editor: Francesco Onorati

Copyright (C) 2016 Su Rin Shin et al. This is an open access article distributed under the Creative Commons Attribution License, which permits unrestricted use, distribution, and reproduction in any medium, provided the original work is properly cited.

The incidence of acute kidney injury after cardiac surgery (CS-AKI) ranges from $33 \%$ to $94 \%$ and is associated with a high incidence of morbidity and mortality. The etiology is suggested to be multifactorial and related to almost all aspects of perioperative management. Numerous studies have reported the risk factors and risk scores and novel biomarkers of AKI have been investigated to facilitate the subclinical diagnosis of AKI. Based on the known independent risk factors, many preventive interventions to reduce the risk of CS-AKI have been tested. However, any single preventive intervention did not show a definite and persistent benefit to reduce the incidence of CS-AKI. Goal-directed therapy has been considered to be a preventive strategy with a substantial level of efficacy. Many pharmacologic agents were tested for any benefit to treat or prevent CS-AKI but the results were conflicting and evidences are still lacking. The present review will summarize the current updated evidences about the risk factors and preventive strategies for CS-AKI.

\section{Introduction}

Postoperative acute kidney injury (AKI) is now well recognized as a frequent and serious postoperative complication after cardiac surgery. It is one of the most significant causes of morbidity and mortality in patients undergoing cardiac surgery. AKI could even evolve to chronic kidney disease $[1,2]$. According to the definition and surgery type, the incidence of postoperative AKI varies widely, from $33 \%$ to $94 \%$ [2-5]. Even small transient increases in serum creatinine that occur in the postoperative period are associated with a decreased patient survival [6]. As there is no effective therapy available for AKI after cardiac surgery $[7,8]$, there is an increasing desire to decrease postoperative AKI to improve clinical outcomes in patients undergoing cardiovascular surgery.

\section{Definition and Classification}

The Acute Dialysis Quality Initiative (ADQI) work group introduced a multilevel classification system for AKI, RIFLE classification in 2004 (Table 1) [9]. This investigators group subsequently published AKIN (acute kidney injury network) criteria which discarded chronic criteria and estimated glomerular filtration rate (GFR) [10]. The same study group recently suggested KDIGO (kidney disease: improving global outcomes) criteria which added RRT and 12 hours of anuria 
TABLE 1: RIFLE, AKIN, and KDIGO classification for AKI diagnosis.

\begin{tabular}{|c|c|c|c|c|c|c|}
\hline \multicolumn{2}{|r|}{ RIFLE } & \multicolumn{2}{|r|}{ AKIN } & \multicolumn{2}{|c|}{ KDIGO } & \multirow{2}{*}{ Urine output* } \\
\hline Criteria & Creatinine definition & Criteria & Creatinine definition & Criteria & Creatinine definition & \\
\hline Risk & $\begin{array}{c}\geq 1.5 \text {-fold increase } \\
\text { from baseline SCr } \\
\text { or decrease in GFR } \\
\geq 25 \%\end{array}$ & Stage 1 & $\begin{array}{c}\geq 0.3 \mathrm{mg} / \mathrm{dL} \text { increase } \\
\text { or } \geq 1.5 \text {-fold increase } \\
\text { from baseline } \mathrm{SCr} \\
\text { within } 48 \mathrm{hrs}\end{array}$ & Stage 1 & $\begin{array}{c}\geq 0.3 \mathrm{mg} / \mathrm{dL} \text { increase } \\
\text { within } 48 \text { hrs or } \\
1.5-1.9 \text { times baseline } \\
\text { within } 7 \text { days }\end{array}$ & $\begin{array}{c}<0.5 \mathrm{~mL} / \mathrm{kg} / \mathrm{h} \text { for } \\
>6 \text { hours }\end{array}$ \\
\hline Injury & $\begin{array}{c}\geq 2 \text {-fold increase from } \\
\text { baseline SCr } \\
\text { or decrease in GFR } \\
\geq 50 \%\end{array}$ & Stage 2 & $\begin{array}{l}\geq 2 \text {-fold increase from } \\
\text { baseline SCr }\end{array}$ & Stage 2 & $\begin{array}{c}2.0-2.9 \text { times baseline } \\
\text { within } 7 \text { days }\end{array}$ & $\begin{array}{c}<0.5 \mathrm{~mL} / \mathrm{kg} / \mathrm{h} \text { for } \\
12 \text { hours }\end{array}$ \\
\hline Failure & $\begin{array}{l}\geq 3 \text {-fold increase from } \\
\text { baseline SCr } \\
\text { or increase to } \\
\geq 4 \mathrm{mg} / \mathrm{dL} \text { or decrease } \\
\text { in GFR } \geq 75 \%\end{array}$ & Stage 3 & $\begin{array}{l}\geq 3 \text {-fold increase from } \\
\text { baseline } \mathrm{SCr} \text { or } \\
\text { increase to } \\
\geq 4.0 \mathrm{mg} / \mathrm{dL} \text { with an } \\
\text { acute increase of } \\
>0.5 \mathrm{mg} / \mathrm{dL} \\
\text { or initiation of RRT }\end{array}$ & Stage 3 & $\begin{array}{l}\geq 3 \text { times baseline } \\
\text { within } 7 \text { days or } \\
\text { increase to } \\
\geq 4.0 \mathrm{mg} / \mathrm{dL} \text { with an } \\
\text { acute increase of } \\
>0.5 \mathrm{mg} / \mathrm{dL} \\
\text { or initiation of RRT }\end{array}$ & $\begin{array}{c}<0.3 \mathrm{~mL} / \mathrm{kg} / \mathrm{h} \text { for } \\
24 \text { hours or anuria } \\
\text { for }>12 \text { hours }\end{array}$ \\
\hline
\end{tabular}

RIFLE: risk, injury, failure, loss, end-stage kidney disease; AKIN: acute kidney injury network; KDIGO: kidney disease: improving global outcomes; SCr: serum creatinine; GFR: glomerular filtration rate; RRT: renal replacement therapy.

${ }^{*}$ Urine output criteria are common to three definitions.

as criteria for Stage 3 AKI. The RIFLE and AKIN criteria are well established criteria [11, 12] but KDIGO criteria needed to be further validated to replace the previous two criteria [13].

\section{Etiology and Risk Prediction of CS-AKI}

The etiology of cardiac surgery-associated AKI (CS-AKI) after cardiac surgery is multifactorial, including ischemiareperfusion injury, inflammation, and oxidative stress [14]. Hemodynamic parameter should also be considered for prerenal AKI, because kidney is susceptible to ischemic damage during renal hypoperfusion by perioperative low cardiac output syndrome and possible cardiogenic shock [15]. As no efficacious therapy for AKI is available at present $[7,8]$, identifying risk factors and a reduction of the risk of AKI would be beneficial $[16,17]$. Several specific risk scores have been developed for AKI or postoperative dialysis following cardiac surgery, and these scores have demonstrated good performance in their study populations (Table 2) [16, 18-23]. The risk factors of these risk scores vary from study to study with some overlap. Some of reported risk factors including preoperative anemia, red blood cells transfusions, and preoperative hypoalbuminemia were considered to be potentially modifiable [17,24], but prospective clinical trials with enough power are required to test whether modification of the modifiable risk factors could really reduce the incidence of AKI. Serum albumin may have a renoprotective effect by improving renal perfusion, inhibiting apoptosis of renal tubular cells, and promoting the proliferation of renal tubular cells [25-27]. However, a recent propensity score matched retrospective study has reported that albumin administration was associated with a dose-dependent risk of AKI [28]. Since Song et al. [29] first reported that prophylactic administration of erythropoietin in patients scheduled for elective CABG can prevent AKI, several randomized controlled trials (RCTs) have been performed in adult patients undergoing cardiac surgery. However, the results were controversial [30].

Cardiopulmonary bypass (CPB) itself has been regarded as a cause of developing CS-AKI. Blood cells are exposed to nonphysiologic surfaces of $\mathrm{CPB}$ circuit and shear forces, resulting in cell lysis and systemic and renal interstitial inflammation [31]. This inflammation causes the systemic inflammatory response syndrome (SIRS), which has been considered as one of the important pathologic mechanisms of CS-AKI. Changes of physiologic pulsatile to nonphysiologic linear flow during CPB exacerbate organ injury presumably by elevating peripheral vascular resistance, leading to poor microcirculation, and increasing tissue edema [31]. A recent retrospective study reported the perioperative neutrophillymphocyte ratio as a predictor of CS-AKI, highlighting the role of SIRS in the pathogenesis of CS-AKI [32]. As a consequence, a long operation time and cardiopulmonary bypass (CPB) duration were identified as a risk factor for AKI [19, 33-38]. Hypoxic renal injury during deep hypothermic circulatory arrest (DHCA) time has been thought to be a risk factor for AKI $[39,40]$, so a long DHCA time may result in a higher incidence of AKI. However, operation time including $\mathrm{CPB}$ and DHCA time is not considered to be modifiable.

A previous RCT demonstrated that general anesthesia with propofol was associated with significant reduction in the incidence of CS-AKI compared with sevoflurane anesthesia [41]. However, due to small sample size and single-center design, large multicenter trial is required to confirm this result. There have been controversies over whether perioperative aprotinin use is associated with renal dysfunction [42-44]. Aprotinin was withdrawn from the market since the BART study [44], but another study suggested that the administration of aprotinin does not increase the risk of renal dysfunction [45]. 
TABLE 2: Risk scoring models for cardiac surgery-associated AKI.

\begin{tabular}{|c|c|c|c|c|c|c|c|}
\hline Variables & $\begin{array}{l}\text { Thakar et } \\
\text { al. [16] }\end{array}$ & $\begin{array}{c}\text { Mehta et } \\
\text { al. [18] }\end{array}$ & $\begin{array}{c}\text { Wijeysundera et } \\
\text { al. [20] }\end{array}$ & $\begin{array}{l}\text { Aronson } \\
\text { et al. [21] }\end{array}$ & $\begin{array}{c}\text { Palomba et } \\
\text { al. [19] }\end{array}$ & $\begin{array}{c}\text { Brown et } \\
\text { al. [22] }\end{array}$ & $\begin{array}{c}\text { Parolari et } \\
\text { al. [23] }\end{array}$ \\
\hline \multicolumn{8}{|l|}{ Demographics } \\
\hline Age & & 0 & & 0 & 0 & 0 & 0 \\
\hline Gender & 0 & & & & & 0 & \\
\hline \multicolumn{8}{|l|}{ Baseline medical conditions } \\
\hline Hypertension & & & & & & 0 & \\
\hline Pulse pressure hypertension & & & & 0 & & & \\
\hline Diabetes mellitus & 0 & 0 & 0 & & & 0 & 0 \\
\hline Preoperative renal dysfunction & 0 & 0 & 0 & 0 & 0 & & 0 \\
\hline Congestive heart failure & 0 & & & 0 & & 0 & \\
\hline Decreased LVEF & 0 & & 0 & & & & \\
\hline Advanced NYHA class & & 0 & & & 0 & & \\
\hline Prior myocardial infarction & & 0 & & 0 & & & \\
\hline Chronic lung disease & 0 & 0 & & & & & \\
\hline Preoperative IABP & 0 & & 0 & & & 0 & \\
\hline Prior cardiac surgery & 0 & 0 & 0 & & & 0 & \\
\hline Emergency operation & 0 & & 0 & & & & \\
\hline Preoperative neutrophilia & & & & & & 0 & \\
\hline \multicolumn{8}{|l|}{ Intraoperative variables } \\
\hline Increased $\mathrm{CPB}$ time & & & & 0 & 0 & & 0 \\
\hline Two inotropes required & & & & 0 & & & 0 \\
\hline Transfusion & & & & & & & 0 \\
\hline Diuretics use & & & & & & & 0 \\
\hline \multicolumn{8}{|l|}{ Postoperative variables } \\
\hline $\mathrm{CVP}>14 \mathrm{~cm} \mathrm{H}_{2} \mathrm{O}$ & & & & & 0 & & \\
\hline Low cardiac output & & & & & 0 & & \\
\hline Inotrope/vasoconstrictor use & & & & & & & 0 \\
\hline Transfusion & & & & & & & 0 \\
\hline Diuretics/antiarrhythmics use & & & & & & & 0 \\
\hline
\end{tabular}

NYHA: New York Heart Association; CPB: cardiopulmonary bypass; CVP: central venous pressure; IABP: intra-aortic balloon pump; LVEF: left ventricular ejection fraction.

\section{Biomarkers of CS-AKI}

Biomarkers of renal injury have been extensively studied recently because these markers can provide early detection of $\mathrm{AKI}$ and prognostic value. Most frequently studied promising biomarkers are neutrophil gelatinase-associated lipocalin (NGAL) and interleukin-18 (IL-18) [46, 47]. Serum cystatin C is also suggested to be a useful predictor of CS-AKI $[48,49]$.

\section{Preventive Interventions by Risk Factor Modification and Hemodynamic Optimization}

There are plenty of studies reporting preventive interventions to mitigate CS-AKI. Numerous small RCTs corroborated the preventive effect of risk factor modifications, but their effects were mostly inconsistent and level of evidence was low. Hemodynamic optimization showed relatively consistent promising results [50]. Prevention of AKI appears to be best delivered by a multimodal approach, because renal injury can occur from multifactorial etiologies.

5.1. Hemodynamic Optimization or Goal-Directed Therapy. Recent retrospective cohort study reported that AKI is associated with intraoperative period of mean arterial pressure (MAP) less than 55 and less than $60 \mathrm{mmHg}$ [51]. This result requires a clinical trial to determine whether interventions that prevent intraoperative hypotension and maintain MAP strictly above 55 and $60 \mathrm{mmHg}$ could help reduce CS-AKI.

Renal perfusion may be preserved by maintaining adequate intravascular volume and cardiac output, mainstay of the protocolized patient care, so-called "goal-directed therapy." These strategies also called "hemodynamic optimization" refer to the perioperative monitoring and maintaining specific hemodynamic goals by means of fluid, transfusion, and inotropes. A previous meta-analysis of 4,220 surgical 
patients tested whether hemodynamic optimization could reduce the incidence of postoperative AKI and concluded that surgical patients receiving perioperative hemodynamic optimization are at decreased risk of renal dysfunction [50]. However, there have been concerns that the administration of hydroxyethyl starch as part of goal-directed therapy is associated with AKI [52-54].

5.2. Fluid, Colloid Administration, and Transfusion. Chloride-rich fluids are associated with worse clinical outcomes compared with balanced solutions [55-57]. Analysis of more than 30,000 adult patients undergoing major abdominal surgery showed that patients receiving $0.9 \%$ saline were prone to require RRT and had greater transfusion requirements and more infectious complications compared to those receiving balanced solution [56]. Another prospective study reported by Yunos et al. with more than 1,500 patients in ICU reported that patients receiving chloride restricted solutions had less AKI and required RRT less often than those receiving chloride-rich solutions [57]. The effect of fluid balance on CS-AKI is studied. In a recent single-center retrospective analysis, postoperative fluid overload was associated with poor short-term outcome of patients with CS-AKI [58].

Multicenter RCTs were published to test whether use of hydroxyethyl starch (colloids) compared with crystalloid solutions alters mortality and renal function in ICU patients with or without sepsis $[59,60]$. They found no difference in short-term mortality and more patients receiving colloids were treated with renal replacement therapy. Recent metaanalyses confirmed that clinical use of colloids was associated with increased risk of AKI and dialysis in critically ill patients [52-54]. Perioperative transfusion is associated with high risk of CS-AKI, but a direct causal relationship between red blood cell transfusion and AKI has not been confirmed [61].

5.3. $C P B$ Parameters. Hypotension during $\mathrm{CPB}$ was not suggested to be associated with development of CS-AKI [62]. However, a prospective observational study showed that mean arterial pressure below the cerebral autoregulation threshold during CPB is independently associated with CS-AKI [63]. Hemodilution during CPB is considered to contribute to CS-AKI by impairment of oxygen delivery to the hypoxic kidney medulla. A retrospective study observed that intraoperative hematocrit $<24 \%$ was associated with increased risk of CS-AKI [64], which was also reported in a recent prospective study [65]. The technology of pulsatile $\mathrm{CPB}$ was developed to mimic physiologic blood flow. However, the theoretical benefit of pulsatile $\mathrm{CPB}$ to improve microcirculation has not yet been proved in a randomized observational study [31], while it showed some benefit in terms of better maintenance of glomerular filtration rate and lower renal tissue injury measured by kidney injury markers including NGAL [66]. Intra-aortic balloon pump (IABP) can produce pulsatile perfusion during $\mathrm{CPB}$ in high-risk patients and a previous RCT enrolling 501 coronary artery bypass graft (CABG) surgery patients demonstrated that IABP-induced pulsatile CPB improved whole-body perfusion and reduced endothelial activation [67]. However, a recent animal study raised concern regarding using IABP to achieve pulsatile perfusion by showing the lowered aortic pressure in the distal aorta and the impaired renal tissue perfusion [68].

5.4. Metabolic Control. Tight blood glucose control (blood glucose $<110 \mathrm{mg} / \mathrm{dL}$ ) was associated with a reduction in the incidence of postoperative mortality and hemodialysis in cardiac surgical patients $[69,70]$. However, these positive findings were questioned by a recent multicenter trial and meta-analysis in critically ill patients $[71,72]$. A meta-analysis pointed out that patients in surgical ICUs appear to benefit from intensive insulin therapy [72]. Hyperuricemia has been associated with an increased risk of CS-AKI [73]. However, a small RCT failed to demonstrate the effect of uric acid lowering therapy on the prevention of CS-AKI [74]. More studies are required to clarify exact relationship between hyperuricemia and CS-AKI.

5.5. Avoid Nephrotoxic Agents. Preoperative combined administration of angiotensin-converting enzyme (ACE) inhibitors, angiotensin receptor blockers (ARB), diuretics, or nonsteroidal anti-inflammatory drugs is associated with increased risk of AKI [75, 76].

5.6. Early Initiation of Renal Replacement Therapy. Elahi et al. suggested that early continuous renal replacement therapy (CRRT) may improve mortality and mortality in severe CSAKI [77]. A meta-analysis from 15 studies and 2955 patients reported that early CRRT could reduce the mortality of patients with AKI [78].

\section{Pharmacologic Renal Protection}

Although a variety of studies have been published, there is no consistent evidence with sufficient power to support routine use of any specific pharmacological drug in preventing CSAKI (Table 3).

6.1. Dopamine and Fenoldopam. Dopamine and fenoldopam, a selective dopamine-1 receptor agonist, are expected to protect renal function due to its renal vasodilatory and natriuretic effect. However, dopamine does not seem to prevent or ameliorate CS-AKI [79]. A previous RCT enrolling 80 patients undergoing cardiac surgery has shown that fenoldopam prevented AKI and major morbidity in the subgroup of patients requiring inotropic support [80]. A metaanalysis from 6 RCTs showed that fenoldopam significantly reduced the incidence of AKI, but no effect on RRT, survival, and length of ICU/hospital stay [81]. Large, multicenter, adequately powered RCTs are required to confirm favorable effect to reduce the risk of $\mathrm{AKI}$.

6.2. Statins. In addition to lipid-lowering properties, statin (3-hydroxy 3-methylglutaryl-CoA reductase inhibitors) possesses antioxidant properties and improves endothelial function and anti-inflammatory action, whose properties provide potential renoprotective effects. A retrospective analysis suggested that early postoperative statin therapy is associated 
TABLE 3: Meta-analyses regarding pharmacologic renal protection for preventing acute kidney injury after cardiac surgery.

\begin{tabular}{|c|c|c|c|c|c|c|c|}
\hline Agent & $\begin{array}{c}\text { Author/ } \\
\text { publication } \\
\text { year }\end{array}$ & $\begin{array}{c}\text { Study type } \\
\text { (RCT/ } \\
\text { observational } \\
\text { study) }\end{array}$ & Outcome & $\begin{array}{c}\text { Patients } \\
\text { (Drug/control, } n)\end{array}$ & $\begin{array}{l}\text { Pooled effect size } \\
\quad \text { (OR, 95\% CI) }\end{array}$ & $p$ value & $\begin{array}{c}I^{2} \\
\text { (heterogeneity) }\end{array}$ \\
\hline Dopamine & $\begin{array}{l}\text { Zacharias et } \\
\text { al. } 2013 \text { [79] }\end{array}$ & 10 & AKI & 541 & $1.36(0.44,4.23)$ & $\begin{array}{l}\text { Not } \\
\text { reported }\end{array}$ & Not reported \\
\hline Fenoldopam & $\begin{array}{l}\text { Zangrillo et } \\
\text { al. } 2012 \text { [81] }\end{array}$ & $5(5 / 0)$ & AKI & $202 / 207$ & $0.41(0.23,0.74)$ & 0.003 & $0 \%$ \\
\hline Fenoldopam & $\begin{array}{l}\text { Zangrillo et } \\
\text { al. } 2012 \text { [81] }\end{array}$ & $4(4 / 0)$ & RRT & $183 / 188$ & $0.67(0.10,4.48)$ & 0.68 & $62 \%$ \\
\hline Statin & $\begin{array}{l}\text { Liakopoulos } \\
\text { et } \\
\text { al. } 2008[100]\end{array}$ & $5(2 / 3)$ & AKI & $4236 / 2172$ & $0.78(0.46,1.31)$ & 0.34 & $58.3 \%$ \\
\hline $\begin{array}{l}\text { Sodium } \\
\text { bicarbonate }\end{array}$ & $\begin{array}{l}\text { Bailey et al. } \\
2015 \text { [89] }\end{array}$ & $3(3 / 0)$ & $*$ & 877 & $1.11(0.77,1.60)$ & 0.45 & Not reported \\
\hline $\begin{array}{l}\text { Sodium } \\
\text { bicarbonate }\end{array}$ & $\begin{array}{c}\text { Tie et al. } 2014 \\
{[91]}\end{array}$ & $5(5 / 0)$ & AKI & 1079 & $0.99(0.78,1.24)$ & 0.911 & $56.1 \%$ \\
\hline Mannitol & $\begin{array}{l}\text { Yang et al. } \\
2014 \text { [101] }\end{array}$ & $4(4 / 0)$ & $\dagger$ & $94 / 93$ & $-2.35(-7.46,2.75)$ & 0.37 & $0 \%$ \\
\hline $\mathrm{N}$-acetylcysteine & $\begin{array}{c}\text { Ho and } \\
\text { Morgan } 2009 \\
{[94]}\end{array}$ & 10 & RRT & $485 / 487$ & $1.04(0.45,2.37)$ & 0.9 & $3.3 \%$ \\
\hline $\mathrm{N}$-acetylcysteine & $\begin{array}{l}\text { Patel et al. } \\
2011 \text { [97] }\end{array}$ & $4(4 / 0)$ & AKI & $453 / 450$ & $0.86(0.66,1.13)$ & 0.29 & $0 \%$ \\
\hline $\mathrm{N}$-acetylcysteine & $\begin{array}{l}\text { Patel et al. } \\
2011 \text { [97] }\end{array}$ & $7(7 / 0)$ & RRT & $503 / 499$ & $0.98(0.50,1.92)$ & 0.96 & $5 \%$ \\
\hline $\begin{array}{l}\text { Atrial natriuretic } \\
\text { peptide }\end{array}$ & $\begin{array}{l}\text { Patel et al. } \\
2011 \text { [97] }\end{array}$ & $1(1 / 0)$ & AKI & $251 / 253$ & $0.35(0.23,0.76)$ & 0.005 & One study \\
\hline $\begin{array}{l}\text { Atrial natriuretic } \\
\text { peptide }\end{array}$ & $\begin{array}{l}\text { Patel et al. } \\
2011 \text { [97] }\end{array}$ & $5(5 / 0)$ & RRT & $427 / 426$ & $0.24(0.10,0.56)$ & 0.001 & $0 \%$ \\
\hline $\begin{array}{l}\text { Brain natriuretic } \\
\text { peptide }\end{array}$ & $\begin{array}{l}\text { Patel et al. } \\
2011 \text { [97] }\end{array}$ & $2(2 / 0)$ & AKI & $186 / 187$ & $0.40(0.21,0.76)$ & 0.005 & $40 \%$ \\
\hline $\begin{array}{l}\text { Brain natriuretic } \\
\text { peptide }\end{array}$ & $\begin{array}{l}\text { Patel et al. } \\
2011[97]\end{array}$ & $2(2 / 0)$ & RRT & $64 / 69$ & $0.80(0.18,3.64)$ & 0.78 & $0 \%$ \\
\hline Steroids adults & $\begin{array}{c}\text { Scrascia et al. } \\
2014 \text { [99] }\end{array}$ & $7(7 / 0)$ & AKI & $291 / 289$ & $1.13(0.53,2.43)$ & $\begin{array}{l}\text { Not } \\
\text { reported }\end{array}$ & $18.3 \%$ \\
\hline MECC & $\begin{array}{c}\text { Scrascia et al. } \\
2014 \text { [99] }\end{array}$ & $6(6 / 0)$ & AKI & $391 / 427$ & $0.47(0.18,1.25)$ & $\begin{array}{l}\text { Not } \\
\text { reported }\end{array}$ & $0 \%$ \\
\hline Leukofiltration & $\begin{array}{c}\text { Scrascia et al. } \\
2014 \text { [99] }\end{array}$ & $4(4 / 0)$ & AKI & $157 / 157$ & $0.18(0.05,0.64)$ & $\begin{array}{c}\text { Not } \\
\text { reported }\end{array}$ & $0 \%$ \\
\hline
\end{tabular}

AKI: acute kidney injury; RRT: renal replacement therapy.

${ }^{*}$ Postoperative increase in serum creatinine concentration of greater than $25 \%$ or $0.5 \mathrm{mg} / \mathrm{dL}$ within the first five postoperative days.

${ }^{\dagger}$ Change of serum creatinine concentration.

with a lower incidence of CS-AKI [82]. However, a large retrospective study and a multicenter prospective cohort study failed to prove that preoperative statin use can decrease the incidence of CS-AKI [83, 84]. Meanwhile, continuing statin before surgery was associated with a lower risk of elevation of AKI biomarkers [84]. Large RCTs with adequate sample size are still required.

6.3. Dexmedetomidine. Dexmedetomidine is a highly selective alpha-2 agonist and has been shown to protect renal function in animal studies by stabilizing sympathetic activation and anti-inflammatory effects and attenuating ischemia/reperfusion injury. A retrospective analysis of 1,133 patients reported that post-bypass dexmedetomidine use was associated with a reduction in incidence of CS-AKI [85]. A recent triple-blinded RCT found that dexmedetomidine infusion for sedation after CABG under $\mathrm{CPB}$ can decrease blood NGAL levels for the first postoperative day in a dose-dependent manner [86]. Cho et al. [87] conducted a placebo-controlled RCT in 200 patients undergoing valvular heart disease and found that dexmedetomidine infusion reduced both incidence and severity of AKI. Current 
evidences of dexmedetomidine are promising, but more RCTs are still required to test the effect of dexmedetomidine on the incidence of CS-AKI.

6.4. Sodium Bicarbonate. Although a small RCT suggested that urinary alkalinization may protect against CS-AKI [88], following large trial and meta-analysis concluded that sodium bicarbonate infusion was not associated with lower incidence of AKI $[89,90]$. Recent meta-analyses concluded that urinary alkalinization may reduce severe AKI in elective CABG $[89,91]$.

6.5. Mannitol. Mannitol, an osmotic diuretic, has been evaluated for its renoprotective property. The effect of mannitol used in the priming fluid for $\mathrm{CPB}$ on renal function was evaluated in previous RCTs, but no difference was observed [92]. A recent prospective observational study has found that mannitol induces a renal vasodilation and increased renal blood flow with no change in filtration fraction or the renal oxygen supply/demand relation in patients with postoperative AKI [93]. More studies are required regarding the therapeutic role of mannitol.

6.6. $\mathrm{N}$-Acetylcysteine. $\mathrm{N}$-acetylcysteine is an antioxidant and free radical scavenger. It has been studied for its potential role to reduce renal oxidative injury that contributes to CS-AKI. However, a recent meta-analysis showed that evidences do not support routine use of $\mathrm{N}$-acetylcysteine to reduce CS-AKI [94].

6.7. Atrial Natriuretic Peptide (ANP) and Brain Natriuretic Peptide (BNP). ANP and BNP block the renin-angiotensinaldosterone system and induce renal arterial vasodilation. Previous studies have shown prophylactic use of ANP or BNP during cardiac surgery increased GFR and urine output and decreased AKI incidence $[95,96]$. A meta-analysis reported that BNP decreased AKI incidence by $10 \%$ [97]. In a RCT of nesiritide, the recombinant human BNP, nesiritide reduced the incidence of AKI compared to controls [98]. However, well-designed, large multicenter RCTs are still required to assess the effect of ANP and BNP on preventing and treating CS-AKI.

6.8. Anti-Inflammatory Strategies. To modulate inflammatory response that contribute to the pathogenesis of AKI, antiinflammatory strategies including glucocorticoid administration, miniaturized extracorporeal circuit, and the use of leukocyte filter have been investigated. A meta-analysis reported that, among these three interventions, only leukocyte filter application reduced renal injury in cardiac surgery patients [99]. However, the authors claimed the necessity of large well-powered trials with uniform and accepted AKI definition.

\section{Conclusions}

AKI is a frequent and severe complication after cardiac surgery that is associated with longer hospital stay and increased short- and long-term mortality. Although there are extensive studies to find interventions to prevent or reduce CS-AKI, preventive strategies are limited and the evidences are still lacking. Considering the multifactorial etiology of CS-AKI, it is less likely that any single intervention can reduce its incidence. Prevention of CS-AKI may require a multimodal approach such as protocolized therapy or combination of several preventive modalities. In addition, any multimodal approach should consider both patient and surgical parameters.

\section{Competing Interests}

The authors declare that there are no competing interests regarding the publication of this paper.

\section{Acknowledgments}

This study was supported by Samsung Biomedical Research Institute grant (2015).

\section{References}

[1] E. A. J. Hoste, G. Clermont, A. Kersten et al., "RIFLE criteria for acute kidney injury are associated with hospital mortality in critically ill patients: A cohort analysis," Critical Care, vol. 10, article R73, 2006.

[2] C. E. Hobson, S. Yavas, M. S. Segal et al., "Acute kidney injury is associated with increased long-term mortality after cardiothoracic surgery," Circulation, vol. 119, no. 18, pp. 24442453, 2009.

[3] W. H. Kim, S. M. Lee, J. W. Choi et al., "Simplified clinical risk score to predict acute kidney injury after aortic surgery," Journal of Cardiothoracic and Vascular Anesthesia, vol. 27, no. 6, pp. 1158-1166, 2013.

[4] P. J. Conlon, M. Stafford-Smith, W. D. White et al., "Acute renal failure following cardiac surgery," Nephrology Dialysis Transplantation, vol. 14, no. 5, pp. 1158-1162, 1999.

[5] M. E. Ostermann, D. Taube, C. J. Morgan, and T. W. Evans, "Acute renal failure following cardiopulmonary bypass: a changing picture," Intensive Care Medicine, vol. 26, no. 5, pp. 565-571, 2000.

[6] A. Lassnigg, D. Schmidlin, M. Mouhieddine et al., "Minimal changes of serum creatinine predict prognosis in patients after cardiothoracic surgery: a prospective cohort study," Journal of the American Society of Nephrology, vol. 15, no. 6, pp. 1597-1605, 2004.

[7] M. H. Rosner and M. D. Okusa, "Acute kidney injury associated with cardiac surgery," Clinical Journal of the American Society of Nephrology, vol. 1, no. 1, pp. 19-32, 2006.

[8] Y. Yang, Y.-X. Wu, and Y.-Z. Hu, "Rosuvastatin treatment for preventing contrast-induced acute kidney injury after cardiac catheterization: a meta-analysis of randomized controlled trials," Medicine, vol. 94, no. 30, Article ID e1226, 2015.

[9] R. Bellomo, C. Ronco, J. A. Kellum, R. L. Mehta, and P. Palevsky, "Acute renal failure-definition, outcome measures, animal models, fluid therapy and information technology needs: the Second International Consensus Conference of the Acute Dialysis Quality Initiative (ADQI) Group," Critical Care, vol. 8, no. 4, pp. R204-212, 2004. 
[10] R. L. Mehta, J. A. Kellum, S. V. Shah et al., "Acute Kidney Injury Network: report of an initiative to improve outcomes in acute kidney injury," Critical Care, vol. 11, no. 2, p. R31, 2007.

[11] J. A. Lopes, P. Fernandes, S. Jorge et al., "Acute kidney injury in intensive care unit patients: a comparison between the RIFLE and the Acute Kidney Injury Network classifications," Critical Care, vol. 12, no. 4, article R110, 2008.

[12] S. M. Bagshaw, C. George, and R. Bellomo, "A comparison of the RIFLE and AKIN criteria for acute kidney injury in critically ill patients," Nephrology Dialysis Transplantation, vol. 23, no. 5, pp. 1569-1574, 2008.

[13] X. Luo, L. Jiang, B. Du, Y. Wen, M. Wang, and X. Xi, "A comparison of different diagnostic criteria of acute kidney injury in critically ill patients," Critical Care, vol. 18, no. 4, article R144, 2014.

[14] R. Bellomo, S. Auriemma, A. Fabbri et al., "The pathophysiology of cardiac surgery-associated acute kidney injury (CSA-AKI)," International Journal of Artificial Organs, vol. 31, no. 2, pp. 166178, 2008.

[15] G. Mariscalco, R. Lorusso, C. Dominici, A. Renzulli, and A. Sala, "Acute kidney injury: a relevant complication after cardiac surgery," Annals of Thoracic Surgery, vol. 92, no. 4, pp. 1539-1547, 2011.

[16] C. V. Thakar, S. Arrigain, S. Worley, J.-P. Yared, and E. P. Paganini, "A clinical score to predict acute renal failure after cardiac surgery," Journal of the American Society of Nephrology, vol. 16, no. 1, pp. 162-168, 2005.

[17] W. H. Kim, M. H. Park, H. J. Kim et al., "Potentially modifiable risk factors for acute kidney injury after surgery on the thoracic aorta: a propensity score matched case-control study," Medicine, vol. 94, no. 2, article e273, 2015.

[18] R. H. Mehta, J. D. Grab, S. M. O’Brien et al., "Bedside tool for predicting the risk of postoperative dialysis in patients undergoing cardiac surgery," Circulation, vol. 114, no. 21, pp. 2208-2216, 2006.

[19] H. Palomba, I. de Castro, A. L. C. Neto, S. Lage, and L. Yu, "Acute kidney injury prediction following elective cardiac surgery: AKICS score," Kidney International, vol. 72, no. 5, pp. 624-631, 2007.

[20] D. N. Wijeysundera, K. Karkouti, J.-Y. Dupuis et al., "Derivation and validation of a simplified predictive index for renal replacement therapy after cardiac surgery," The Journal of the American Medical Association, vol. 297, no. 16, pp. 1801-1809, 2007.

[21] S. Aronson, M. L. Fontes, Y. Miao, and D. T. Mangano, "Risk index for perioperative renal dysfunction/failure: critical dependence on pulse pressure hypertension," Circulation, vol. 115, no. 6, pp. 733-742, 2007.

[22] J. R. Brown, R. P. Cochran, B. J. Leavitt et al., "Multivariable prediction of renal insufficiency developing after cardiac surgery," Circulation, vol. 116, no. 11, pp. I139-I143, 2007.

[23] A. Parolari, L. L. Pesce, D. Pacini et al., "Risk factors for perioperative acute kidney injury after adult cardiac surgery: role of perioperative management," Annals of Thoracic Surgery, vol. 93, no. 2, pp. 584-591, 2012.

[24] K. Karkouti, D. N. Wijeysundera, T. M. Yau et al., "Acute kidney injury after cardiac surgery: focus on modifiable risk factors," Circulation, vol. 119, no. 4, pp. 495-502, 2009.

[25] R. Dixon and N. J. Brunskill, "Activation of mitogenic pathways by albumin in kidney proximal tubule epithelial cells: implications for the pathophysiology of proteinuric states," Journal of the American Society of Nephrology, vol. 10, no. 7, pp. 1487-1497, 1999.
[26] J. Iglesias, V. E. Abernethy, Z. Wang, W. Lieberthal, J. S. Koh, and J. S. Levine, "Albumin is a major serum survival factor for renal tubular cells and macrophages through scavenging of ROS," American Journal of Physiology -Renal Physiology, vol. 277, no. 5, pp. F711-F722, 1999.

[27] M. A. Kaufmann, I. Castelli, H. Pargger, and L. J. Drop, "Nitric oxide dose-response study in the isolated perfused rat kidney after inhibition of endothelium-derived relaxing factor synthesis: the role of serum albumin," Journal of Pharmacology and Experimental Therapeutics, vol. 273, no. 2, pp. 855-862, 1995.

[28] A. J. Frenette, J. Bouchard, P. Bernier et al., "Albumin administration is associated with acute kidney injury in cardiac surgery: a propensity score analysis," Critical Care, vol. 18, no. 6, article 602, 2014.

[29] Y. R. Song, T. Lee, S. J. You et al., "Prevention of acute kidney injury by erythropoietin in patients undergoing coronary artery bypass grafting: a pilot study," American Journal of Nephrology, vol. 30, no. 3, pp. 253-260, 2009.

[30] H.-T. Tie, M.-Z. Luo, D. Lin, M. Zhang, J.-Y. Wan, and Q.-C. Wu, "Erythropoietin administration for prevention of cardiac surgery-associated acute kidney injury: a meta-analysis of randomized controlled trials," European Journal of CardioThoracic Surgery, vol. 48, no. 1, pp. 32-39, 2015.

[31] P. W. G. Elbers, J. Wijbenga, F. Solinger et al., "Direct observation of the human microcirculation during cardiopulmonary bypass: effects of pulsatile perfusion," Journal of Cardiothoracic and Vascular Anesthesia, vol. 25, no. 2, pp. 250-255, 2011.

[32] W. H. Kim, J. Y. Park, S. H. Ok, I. W. Shin, and J. T. Sohn, "Association between the neutrophil/lymphocyte ratio and acute kidney injury after cardiovascular surgery: a retrospective observational study," Medicine, vol. 94, no. 43, p. e1867, 2015.

[33] L. Englberger, R. M. Suri, K. L. Greason et al., "Deep hypothermic circulatory arrest is not a risk factor for acute kidney injury in thoracic aortic surgery," Journal of Thoracic and Cardiovascular Surgery, vol. 141, no. 2, pp. 552-558, 2011.

[34] A. D’Onofrio, D. Cruz, I. Bolgan et al., "RIFLE criteria for cardiac surgery-associated acute kidney injury: risk factors and outcomes," Congestive Heart Failure, vol. 16, supplement 1, pp. S32-S36, 2010.

[35] G. J. Arnaoutakis, A. Bihorac, T. D. Martin et al., "RIFLE criteria for acute kidney injury in aortic arch surgery," The Journal of Thoracic and Cardiovascular Surgery, vol. 134, no. 6, pp. 15541561, 2007.

[36] T. Bove, M. G. Calabrò, G. Landoni et al., "The incidence and risk of acute renal failure after cardiac surgery," Journal of Cardiothoracic and Vascular Anesthesia, vol. 18, no. 4, pp. 442445, 2004.

[37] G. U. Roh, J. W. Lee, S. B. Nam, J. Lee, J.-R. Choi, and Y. H. Shim, "Incidence and risk factors of acute kidney injury after thoracic aortic surgery for acute dissection," Annals of Thoracic Surgery, vol. 94, no. 3, pp. 766-771, 2012.

[38] A. B. Kumar, M. Suneja, E. O. Bayman, G. D. Weide, and M. Tarasi, "Association between postoperative acute kidney injury and duration of cardiopulmonary bypass: a meta-analysis," Journal of Cardiothoracic and Vascular Anesthesia, vol. 26, no. 1, pp. 64-69, 2012.

[39] M. Brezis and S. Rosen, "Hypoxia of the renal medulla-its implications for disease," The New England Journal of Medicine, vol. 332, no. 10, pp. 647-655, 1995. 
[40] P. Devarajan, "Update on mechanisms of ischemic acute kidney injury," Journal of the American Society of Nephrology, vol. 17, no. 6, pp. 1503-1520, 2006.

[41] Y. C. Yoo, J. K. Shim, Y. Song, S. Y. Yang, and Y. L. Kwak, "Anesthetics influence the incidence of acute kidney injury following valvular heart surgery," Kidney International, vol. 86, no. 2, pp. 414-422, 2014.

[42] J. G. T. Augoustides, "Con: aprotinin should not be used in cardiac surgery with cardiopulmonary bypass," Journal of Cardiothoracic and Vascular Anesthesia, vol. 21, no. 2, pp. 302304, 2007.

[43] J. G. T. Augoustides, A. Pochettino, E. A. Ochroch et al., "Renal dysfunction after thoracic aortic surgery requiring deep hypothermic circulatory arrest: definition, incidence, and clinical predictors," Journal of Cardiothoracic and Vascular Anesthesia, vol. 20, no. 5, pp. 673-677, 2006.

[44] D. A. Fergusson, P. C. Hébert, C. D. Mazer et al., "A comparison of aprotinin and lysine analogues in high-risk cardiac surgery," The New England Journal of Medicine, vol. 358, no. 22, pp. 23192331, 2008.

[45] C. T. Mora Mangano, M. J. Neville, P. H. Hsu, I. Mignea, J. King, and D. C. Miller, "Aprotinin, blood loss, and renal dysfunction in deep hypothermic circulatory arrest," Circulation, vol. 104, no. 12, supplement 1, pp. I276-I281, 2001.

[46] D. R. McIlroy, G. Wagener, and H. T. Lee, "Neutrophil gelatinase-associated lipocalin and acute kidney injury after cardiac surgery: the effect of baseline renal function on diagnostic performance," Clinical Journal of the American Society of Nephrology, vol. 5, no. 2, pp. 211-219, 2010.

[47] C. R. Parikh, S. G. Coca, H. Thiessen-Philbrook et al., "Postoperative biomarkers predict acute kidney injury and poor outcomes after adult cardiac surgery," Journal of the American Society of Nephrology, vol. 22, no. 9, pp. 1748-1757, 2011.

[48] M. G. Shlipak, S. G. Coca, Z. Wang et al., "Presurgical serum cystatin C and risk of acute kidney injury after cardiac surgery," American Journal of Kidney Diseases, vol. 58, no. 3, pp. 366-373, 2011.

[49] A. Spahillari, C. R. Parikh, K. Sint et al., "Serum cystatin Cversus creatinine-based definitions of acute kidney injury following cardiac surgery: A Prospective Cohort Study," American Journal of Kidney Diseases, vol. 60, no. 6, pp. 922-929, 2012.

[50] N. Brienza, M. T. Giglio, M. Marucci, and T. Fiore, "Does perioperative hemodynamic optimization protect renal function in surgical patients? A meta-analytic study," Critical Care Medicine, vol. 37, no. 6, pp. 2079-2090, 2009.

[51] L. Y. Sun, D. N. Wijeysundera, G. A. Tait, and W. S. Beattie, "Association of intraoperative hypotension with acute kidney injury after elective noncardiac surgery," Anesthesiology, vol. 123, no. 3, pp. 515-523, 2015.

[52] N. Haase, A. Perner, L. I. Hennings et al., "Hydroxyethyl starch 130/0.38-0.45 versus crystalloid or albumin in patients with sepsis: systematic review with meta-analysis and trial sequential analysis," The British Medical Journal, vol. 346, article f839, 2013.

[53] A. B. Dart, T. C. Mutter, C. A. Ruth, and S. P. Taback, "Hydroxyethyl starch (HES) versus other fluid therapies: effects on kidney function," Cochrane Database of Systematic Reviews, no. 1, Article ID CD007594, 2010.

[54] R. Zarychanski, A. M. Abou-Setta, A. F. Turgeon et al., "Association of hydroxyethyl starch administration with mortality and acute kidney injury in critically ill patients requiring volume resuscitation: a systematic review and meta-analysis,"
The Journal of the American Medical Association, vol. 309, no. 7, pp. 678-688, 2013.

[55] S. A. McCluskey, K. Karkouti, D. Wijeysundera, L. Minkovich, G. Tait, and W. S. Beattie, "Hyperchloremia after noncardiac surgery is independently associated with increased morbidity and mortality: a propensity-matched cohort study," Anesthesia \& Analgesia, vol. 117, no. 2, pp. 412-421, 2013.

[56] A. D. Shaw, S. M. Bagshaw, S. L. Goldstein et al., "Major complications, mortality, and resource utilization after open abdominal surgery: 0.9\% saline compared to plasma-lyte," Annals of Surgery, vol. 255, no. 5, pp. 821-829, 2012.

[57] N. M. Yunos, R. Bellomo, F. C. Hegarty, D. Story, L. Ho, and M. Bailey, "Association between a chloride-liberal vs chloriderestrictive intravenous fluid administration strategy and kidney injury in critically ill adults," The Journal of the American Medical Association, vol. 308, no. 15, pp. 1566-1572, 2012.

[58] J. Xu, B. Shen, Y. Fang et al., "Postoperative fluid overload is a useful predictor of the short-term outcome of renal replacement therapy for acute kidney injury after cardiac surgery," Medicine, vol. 94, no. 33, Article ID e1360, 2015.

[59] D. Annane, S. Siami, S. Jaber et al., "Effects of fluid resuscitation with colloids vs crystalloids on mortality in critically ill patients presenting with hypovolemic shock-The CRISTAL randomized trial," Journal of the American Medical Association, vol. 310, no. 17, pp. 1809-1817, 2013.

[60] J. A. Myburgh, S. Finfer, R. Bellomo et al., "Hydroxyethyl starch or saline for fluid resuscitation in intensive care," The New England Journal of Medicine, vol. 367, no. 20, pp. 1901-1911, 2012.

[61] K. Karkouti, D. N. Wijeysundera, T. M. Yau et al., "Influence of erythrocyte transfusion on the risk of acute kidney injury after cardiac surgery differs in anemic and nonanemic patients," Anesthesiology, vol. 115, no. 3, pp. 523-530, 2011.

[62] E. Sirvinskas, R. Benetis, L. Raliene, and J. Andrejaitiene, "The influence of mean arterial blood pressure during cardiopulmonary bypass on postoperative renal dysfunction in elderly patients," Perfusion, vol. 27, no. 3, pp. 193-198, 2012.

[63] M. Ono, G. J. Arnaoutakis, D. M. Fine et al., "Blood pressure excursions below the cerebral autoregulation threshold during cardiac surgery are associated with acute kidney injury," Critical Care Medicine, vol. 41, no. 2, pp. 464-471, 2013.

[64] R. H. Habib, A. Zacharias, T. A. Schwann et al., "Role of hemodilutional anemia and transfusion during cardiopulmonary bypass in renal injury after coronary revascularization: implications on operative outcome," Critical Care Medicine, vol. 33, no. 8, pp. 1749-1756, 2005.

[65] R. A. Huybregts, R. de Vroege, E. K. Jansen, A. W. van Schijndel, H. M. Christiaans, and W. van Oeveren, "The association of hemodilution and transfusion of red blood cells with biochemical markers of splanchnic and renal injury during cardiopulmonary bypass," Anesthesia and Analgesia, vol. 109, no. 2, pp. 331-339, 2009.

[66] A. D. Milano, M. Dodonov, W. Van Oeveren et al., "Pulsatile cardiopulmonary bypass and renal function in elderly patients undergoing aortic valve surgery," European Journal of CardioThoracic Surgery, vol. 47, no. 2, pp. 291-298, 2015.

[67] G. F. Serraino, R. Marsico, G. Musolino et al., "Pulsatile cardiopulmonary bypass with intra-aortic balloon pump improves organ function and reduces endothelial activation," Circulation Journal, vol. 76, no. 5, pp. 1121-1129, 2012. 
[68] S. Lundemoen, V. L. Kvalheim, O. Svendsen et al., "Intraaortic counterpulsation during cardiopulmonary bypass impairs distal organ perfusion," Annals of Thoracic Surgery, vol. 99, no. 2, pp. 619-625, 2015.

[69] P. Lecomte, B. Van Vlem, J. Coddens et al., "Tight perioperative glucose control is associated with a reduction in renal impairment and renal failure in non-diabetic cardiac surgical patients," Critical Care, vol. 12, no. 6, article R154, 2008.

[70] G. van den Berghe, P. Wouters, F. Weekers et al., "Intensive insulin therapy in critically ill patients," The New England Journal of Medicine, vol. 345, no. 19, pp. 1359-1367, 2001.

[71] S. Finfer, R. Bellomi, D. Blair et al., "Intensive versus conventional glucose control in critically Ill patients," The New England Journal of Medicine, vol. 360, no. 13, pp. 1283-1297, 2009.

[72] D. E. G. Griesdale, R. J. de Souza, R. M. van Dam et al., "Intensive insulin therapy and mortality among critically ill patients: a meta-analysis including NICE-SUGAR study data," Canadian Medical Association Journal, vol. 180, no. 8, pp. 821827,2009

[73] K. W. Joung, J. Y. Jo, W. J. Kim et al., "Association of preoperative uric acid and acute kidney injury following cardiovascular surgery," Journal of Cardiothoracic and Vascular Anesthesia, vol. 28, no. 6, pp. 1440-1447, 2014.

[74] A. A. Ejaz, B. Dass, V. Lingegowda et al., "Effect of uric acid lowering therapy on the prevention of acute kidney injury in cardiovascular surgery," International Urology and Nephrology, vol. 45, no. 2, pp. 449-458, 2013.

[75] T. Dreischulte, D. R. Morales, S. Bell, and B. Guthrie, "Combined use of nonsteroidal anti-inflammatory drugs with diuretics and/or renin-angiotensin system inhibitors in the community increases the risk of acute kidney injury," Kidney International, vol. 88, no. 2, pp. 396-403, 2015.

[76] F. Lapi, L. Azoulay, H. Yin, S. J. Nessim, and S. Suissa, “Concurrent use of diuretics, angiotensin converting enzyme inhibitors, and angiotensin receptor blockers with non-steroidal antiinflammatory drugs and risk of acute kidney injury: Nested Case-control Study," British Medical Journal, vol. 346, article e8525, 2013.

[77] M. Elahi, S. Asopa, A. Pflueger, N. Hakim, and B. Matata, "Acute kidney injury following cardiac surgery: impact of early versus late haemofiltration on morbidity and mortality," European Journal of Cardio-Thoracic Surgery, vol. 35, no. 5, pp. 854-863, 2009.

[78] X. Wang and W. Jie Yuan, "Timing of initiation of renal replacement therapy in acute kidney injury: a systematic review and meta-analysis," Renal Failure, vol. 34, no. 3, pp. 396-402, 2012.

[79] M. Zacharias, M. Mugawar, G. P. Herbison et al., "Interventions for protecting renal function in the perioperative period," The Cochrane Database of Systematic Reviews, vol. 9, Article ID CD003590, 2013.

[80] M. Ranucci, D. de Benedetti, C. Bianchini et al., "Effects of fenoldopam infusion in complex cardiac surgical operations: a prospective, randomized, double-blind, placebo-controlled study," Minerva Anestesiologica, vol. 76, no. 4, pp. 249-259, 2010.

[81] A. Zangrillo, G. G. L. Biondi-Zoccai, E. Frati et al., "Fenoldopam and acute renal failure in cardiac surgery: a meta-analysis of randomized placebo-controlled trials," Journal of Cardiothoracic and Vascular Anesthesia, vol. 26, no. 3, pp. 407-413, 2012.

[82] F. T. Billings IV, M. Pretorius, E. D. Siew, C. Yu, and N. J. Brown, "Early postoperative statin therapy is associated with a lower incidence of acute kidney injury after cardiac surgery," Journal of Cardiothoracic and Vascular Anesthesia, vol. 24, no. 6, pp. 913920, 2010.

[83] M. Y. Argalious, J. E. Dalton, T. Sreenivasalu, J. O’Hara, and D. I. Sessler, "The association of preoperative statin use and acute kidney injury after noncardiac surgery," Anesthesia and Analgesia, vol. 117, no. 4, pp. 916-923, 2013.

[84] A. O. Molnar, C. R. Parikh, S. G. Coca et al., "Association between preoperative statin use and acute kidney injury biomarkers in cardiac surgical procedures," Annals of Thoracic Surgery, vol. 97, no. 6, pp. 2081-2087, 2014.

[85] F. Ji, Z. Li, J. N. Young, A. Yeranossian, and H. Liu, "Post-bypass dexmedetomidine use and postoperative acute kidney injury in patients undergoing cardiac surgery with cardiopulmonary bypass," PLoS ONE, vol. 8, no. 10, Article ID e77446, 2013.

[86] O. O. Balkanay, D. Goksedef, S. N. Omeroglu, and G. Ipek, “The dose-related effects of Dexmedetomidine on renal functions and serum neutrophil gelatinase-associated lipocalin values after coronary artery bypass grafting: a randomized, tripleblind, placebo-controlled study," Interactive Cardiovascular and Thoracic Surgery, vol. 20, no. 2, pp. 209-214, 2015.

[87] J. S. Cho, J.-K. Shim, S. Soh, M. K. Kim, and Y.-L. Kwak, "Perioperative dexmedetomidine reduces the incidence and severity of acute kidney injury following valvular heart surgery," Kidney International, vol. 89, no. 3, pp. 693-700, 2016.

[88] M. Haase, A. Haase-Fielitz, R. Bellomo et al., "Sodium bicarbonate to prevent increases in serum creatinine after cardiac surgery: a pilot double-blind, randomized controlled trial," Critical Care Medicine, vol. 37, no. 1, pp. 39-47, 2009.

[89] M. Bailey, S. McGuinness, M. Haase et al., "Sodium bicarbonate and renal function after cardiac surgery: a prospectively planned individual patient meta-analysis," Anesthesiology, vol. 122, no. 2, pp. 294-306, 2015.

[90] M. Haase, A. Haase-Fielitz, M. Plass et al., "Prophylactic perioperative sodium bicarbonate to prevent acute kidney injury following open heart surgery: a multicenter double-blinded randomized controlled trial," PLoS Medicine, vol. 10, no. 4, Article ID e1001426, 2013.

[91] H. T. Tie, M. Z. Luo, M. J. Luo, M. Zhang, Q. C. Wu, and J. Y. Wan, "Sodium bicarbonate in the prevention of cardiac surgeryassociated acute kidney injury: a systematic review and metaanalysis," Critical Care, vol. 18, no. 5, article 517, 2014.

[92] K. G. Yallop, S. V. Sheppard, and D. C. Smith, "The effect of mannitol on renal function following cardio-pulmonary bypass in patients with normal pre-operative creatinine," Anaesthesia, vol. 63 , no. 6 , pp. 576-582, 2008.

[93] G. Bragadottir, B. Redfors, and S.-E. Ricksten, "Mannitol increases renal blood flow and maintains filtration fraction and oxygenation in postoperative acute kidney injury: a prospective interventional study," Critical Care, vol. 16, no. 4, article R159, 2012.

[94] K. M. Ho and D. J. R. Morgan, "Meta-analysis of Nacetylcysteine to prevent acute renal failure after major surgery," American Journal of Kidney Diseases, vol. 53, no. 1, pp. 33-40, 2009.

[95] A. Sezai, M. Hata, T. Niino et al., "Influence of continuous infusion of low-dose human atrial natriuretic peptide on renal function during cardiac surgery: a randomized controlled study," Journal of the American College of Cardiology, vol. 54, no. 12, pp. 1058-1064, 2009.

[96] V. Lingegowda, Q. C. Van, M. Shimada et al., "Long-term outcome of patients treated with prophylactic nesiritide for 
the prevention of acute kidney injury following cardiovascular surgery," Clinical Cardiology, vol. 33, no. 4, pp. 217-221, 2010.

[97] N. N. Patel, C. A. Rogers, G. D. Angelini, and G. J. Murphy, "Pharmacological therapies for the prevention of acute kidney injury following cardiac surgery: a systematic review," Heart Failure Reviews, vol. 16, no. 6, pp. 553-567, 2011.

[98] A. A. Ejaz, T. D. Martin, R. J. Johnson et al., "Prophylactic nesiritide does not prevent dialysis or all-cause mortality in patients undergoing high-risk cardiac surgery," Journal of Thoracic and Cardiovascular Surgery, vol. 138, no. 4, pp. 959964, 2009.

[99] G. Scrascia, P. Guida, C. Rotunno, L. de Luca Tupputi Schinosa, and D. Paparella, "Anti-inflammatory strategies to reduce acute kidney injury in cardiac surgery patients: a meta-analysis of randomized controlled trials," Artificial Organs, vol. 38, no. 2, pp. 101-112, 2014.

[100] O. J. Liakopoulos, Y.-H. Choi, P. L. Haldenwang et al., "Impact of preoperative statin therapy on adverse postoperative outcomes in patients undergoing cardiac surgery: a meta-analysis of over 30,000 patients," European Heart Journal, vol. 29, no. 12, pp. 1548-1559, 2008.

[101] B. Yang, J. Xu, F. Xu et al., "Intravascular administration of mannitol for acute kidney injury prevention: a systematic review and meta-analysis," PLoS ONE, vol. 9, no. 1, Article ID e85029, 2014. 


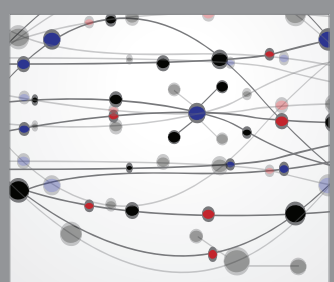

The Scientific World Journal
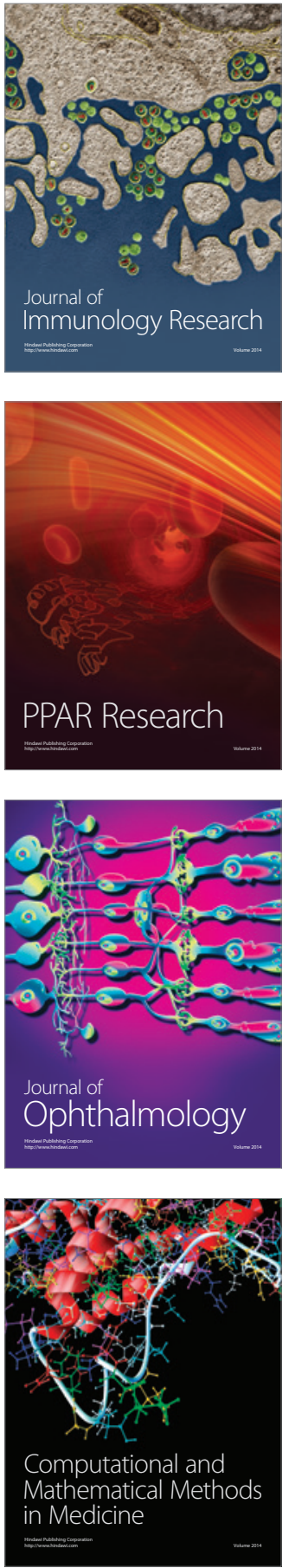

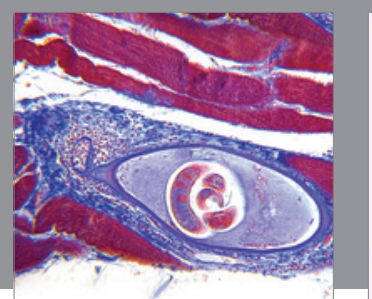

Gastroenterology Research and Practice

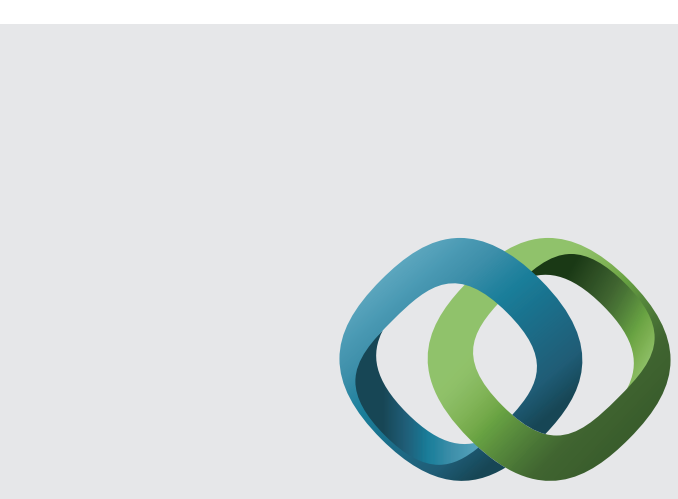

\section{Hindawi}

Submit your manuscripts at

http://www.hindawi.com
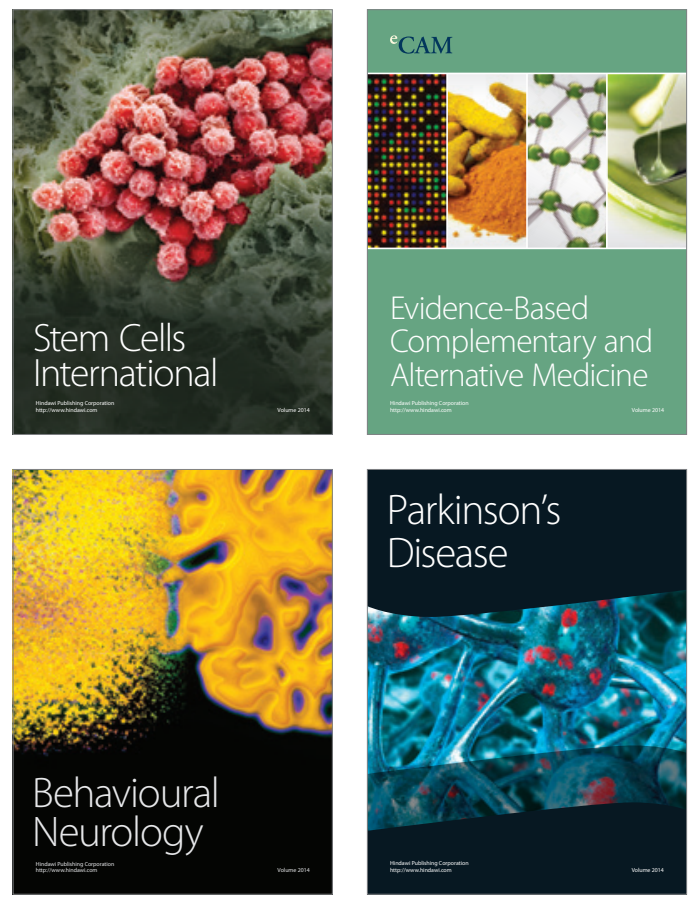
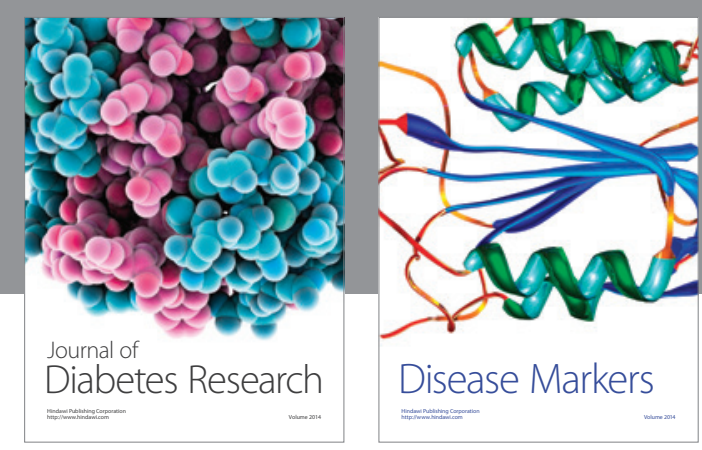

Disease Markers
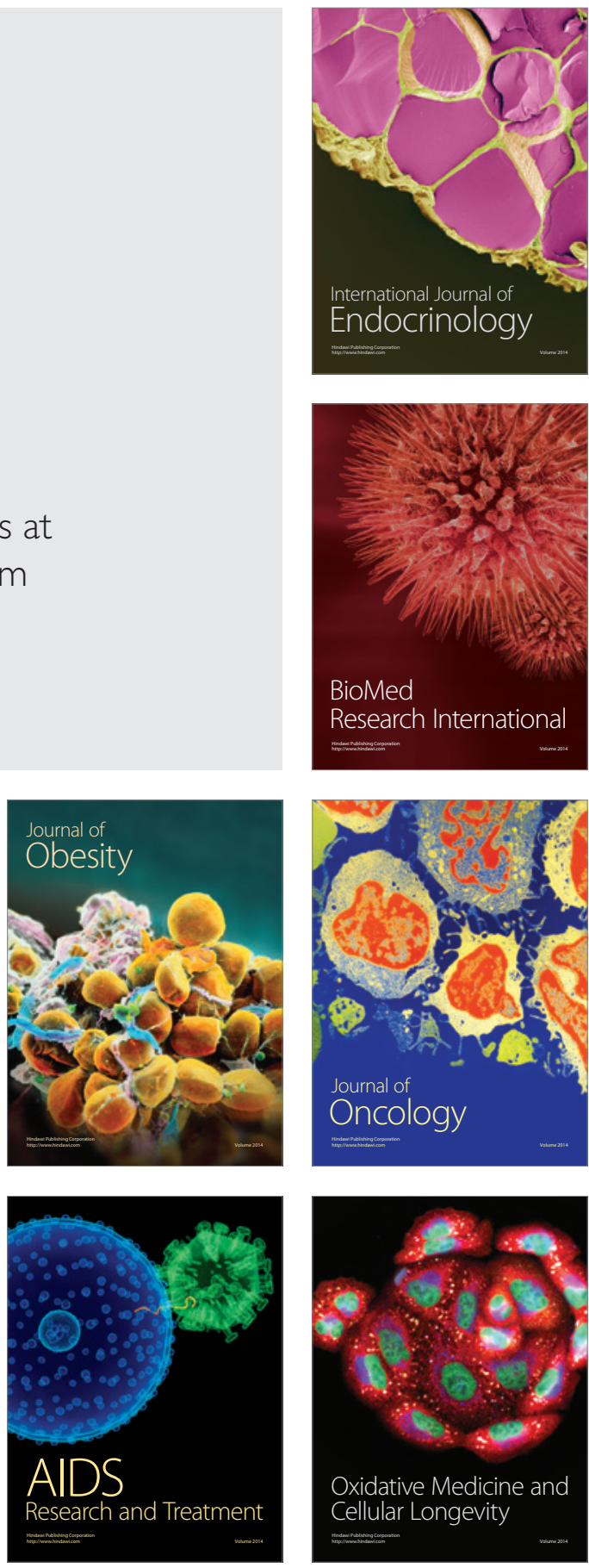